\title{
The Federal Budget and Economic Stabilization
}

\begin{abstract}
$\mathrm{T}_{\mathrm{H}}$
HE PRESIDENT'S Council of Economic Advisers forecasts 1967 gross national product at $\$ 787$ billion in current prices, an increase of about 6.5 per cent over 1966. This increase consists of an advance of nearly 4 per cent in real output and an increase of slightly more than 2.5 per cent in prices.

The Council's forecast, or plan, is constructed in large measure on a Federal budget program that produces in calendar 1967 about a $\$ 4$ billion deficit on a national income accounts basis." A 14.3 per cent increase in Federal spending and an 11.3 per cent rise in revenues underlie this projected deficit. The expected increase in revenues will result from several factors, including continued advance in total income and a proposed 6 per cent surcharge on personal and corporate income taxes effective July 1.
\end{abstract}

The Federal budget program and the Annual Report of the Council of Economic Advisers (CEA) together can be viewed as a national economic plan in the spirit of the Employment Act of 1946. The presentation of the CEA is based, in considerable measure, on the popular theory that Federal budget policy to a major degree can control total demand and thereby exert a primary infuence on changes in real output and prices. Budget policy is presumably designed to achieve an optimum level of demand compatible with the goals of high employment, real growth, relative price stability, and equilibrium in the nation's balance of payments.

In contrast with the fiscal policy theory of economic stabilization there is an alternative school of thought which places primary emphasis on control of monetary variables as a vehicle for infuencing total

\footnotetext{
1 Annual Report of the Counct of Economic Advisers (January 1967), pp. 62-63.

2The national income accounts budget summarizes the receipts and expenditures of the Federal Government sector as an integrated part of the recorded activities of all sectors of the economy. For expanded discussion of this and other fiscal measures, see the appendix, "Budget Concepts and Definitions," p. 11 .
}

spending. It is the belief of this school that monetary factors play a dominant role in the determination of total demand.:

The theory implicit in the following presentation is that the combination of stabilization policies, rather than fiscal or monetary policy alone, in large part determines total demand. Consequently, this discussion of the Federal budget alludes frequently to the role of monetary policy in national economic developments. The purpose of this article is to summarize the proposed Federal budget program for calendar 1967 and to examine its implications as a part of total stabilization policy,

Although the Federal budget receives considerable attention at this particular time of year, it seems that in the interest of a dynamic and effective stabilization policy, or even of a neutral policy, the budget program should be reviewed continuously throughout the year. Evaluations are made privately on a continuous basis, but an official midyear budget review (with revised projections) was not released to the public in 1966. To assure a free and fully-informed discussion and interchange of ideas both inside and outside of Government, it would be desirable to have official revised projections frequently, possibly on a quarterly basis. ${ }^{+}$A midyear review in July or August after Congress has made most of its decisions would seem more reliable for the ensuing year than the 12month forecast made in Jamuary. The CEA Report focuses primarily on the immediate 12 months, while

\footnotetext{
3The 1967 Report pays considerable homage to the role that monetary policy played in restraining total demand in 1966. The appearnince of such an acknowledgment distinguishes the 1967 Report from previous ones, in which monetary policy was seeningly considered supportive (for fiscal policy) rather than active in affecting total demand.

4 A similar recommendation has recently been made by the foint Economic Commitee of Congress. Although revised budgez profections are not made available, data on realized expencitures and revenues ate readily available. See, e.t., the Survey of Current Business. For a brief quarterly analysis of these data, see "Federal Budget Trends" a release of the Federal Reserve Bank of St. Louis.
} 
the Budget concentrates on the 12-month period beginning next July $1 .{ }^{*}$

To form a basis for a discussion of budget policy in future months, this article summarizes and evaluates economic developments, budget conditions, and monetary developments in calendar 1966. The budget program through June 1968 is then summarized and analyzed within a framework emphasizing total stabilization policy. An appendix is provided that discusses alternative budget measures.

\section{Budget Policy and Economic and Monetary Conditions in 1966}

Real economic activity advanced rapidly in 1966, but advances were constrained by the size of the labor force and limitations on plant capacity. Employment, production, and income all increased, though less rapidly than in 1965 when some economic slack remained. ${ }^{6}$ As a result of total demand pressing on available resources, prices rose significantly, particularly early in the year. In an attempt to limit excessive total demand and price increases, monetary expansion was restricted begiming in the spring. Intense demands for credit produced rising interest rates early in the year, while limitations on credit expansion accelerated the rise during the summer.

The Federal budget, on balance, was a strong force underlying the buoyant economic situation in 1966 . Government expenditures grew rapidly as spending for defense and health, education, and welfare programs rose sharply. Federal revenues also increased rapidly, partly in response to rising money incomes but also in some measure because of increases in tax rates.

\section{Resource Transfers in 1966}

Total income and output showed advances substantial enough to keep the economy at high employment during 1966. Real output (GNP in constant

\footnotetext{
5 Since there is some evidence to support the view that the budget affects economic activify with some lag, see, e.g., Albert Ando and E. Cary Brown, "Lags in Fiscal Policy," Stabilization Policies, Research Studies prepared for the Commission on Money and Credit (Englewood Cliffs, N. J.: Prentice-Hall, Inc., 1963), it would seem that the budget for fiscal 1968 (year ending June 30, 1968) must afford a basis for an economic plan for a year beginning in, say, October 1967 or January 1968 . If the primany concern of the Economic Report is the state of the economy in calendar 1967, it would seem that the budget for the year ending June 30,1967 , is more relevant than the budget for the year ending June $30,1968$.

${ }^{6}$ For an extended discussion of economic developments in 1966, see the December 1966 issue of this Review.
}

dollars) rose 4.1 per cent in the year ended in the fourth quarter of 1966, with the advance most rapid in the first quarter.

The year 1966 was marked by the necessity to allocate resources to military use more rapidly than total available resources were growing. Such a transfer of resources is facilitated if there is a considerable quantity of unused resources in the economy, as was the case at the outbreak of the Korean conflict. The Vietnam war was escalated at a time when there was very little slack in the economy.

At times of high employment and near-capacity levels of output, a resource transfer from civilian use to military use is normally effected by either tax increases or a system of Government controls. Neither route was followed with respect to the Vietnam buildup in late 1965 and 1966. Instead, the price mechanism was utilized to effect the resource transfer, i.e, the Federal Government bid away goods and services from civilian use for the war effort.

\section{SELECTED EXPENDITURES AS A PER CENT OF GNP}

\begin{tabular}{|c|c|c|c|}
\hline Quarter & $\begin{array}{l}\text { National } \\
\text { Defense }\end{array}$ & $\begin{array}{c}\text { Consumer } \\
\text { Durable Goods }\end{array}$ & $\begin{array}{c}\text { Residential } \\
\text { Structures }\end{array}$ \\
\hline 19641 & 8.1 & 9.3 & 4,6 \\
\hline 2 & 8.2 & 9.5 & 4.4 \\
\hline 3 & 7.8 & 9.6 & 4.3 \\
\hline 4 & 7.5 & 9.1 & 4.1 \\
\hline 19651 & 7.3 & 9.9 & 4.2 \\
\hline 2 & 7.3 & 9.6 & 4.2 \\
\hline 3 & 7.4 & 9.7 & 4.0 \\
\hline 4 & 7.5 & 9.7 & 3.9 \\
\hline 19661 & 7.6 & 9.7 & 4.0 \\
\hline 2 & 7.8 & 9.2 & 3.8 \\
\hline 3 & 8.3 & 9.4 & 3.3 \\
\hline 4 & 8.6 & 9.2 & 2.9 \\
\hline
\end{tabular}

Source: U. S. Department of Commerce.

Overall price increases thus operated as a silent tax in the absence of more restrictive fiscal or monetary actions. The growth of real after-tax personal income slowed as prices rose faster relative to money incomes than previously. Associated with the slowdown in the growth of real spendable income was a decline in real demand for civilian goods, in particular for automobiles and housing.

In response to excessive dollar demand for goods and services, and thereby for loan funds, and to some extent to restriction on monetary expansion beginning in the spring of 1966, interest rates rose. This increase in the price of credit helped to effect the transfer of resources by discouraging demand for those goods where capital and interest are important 


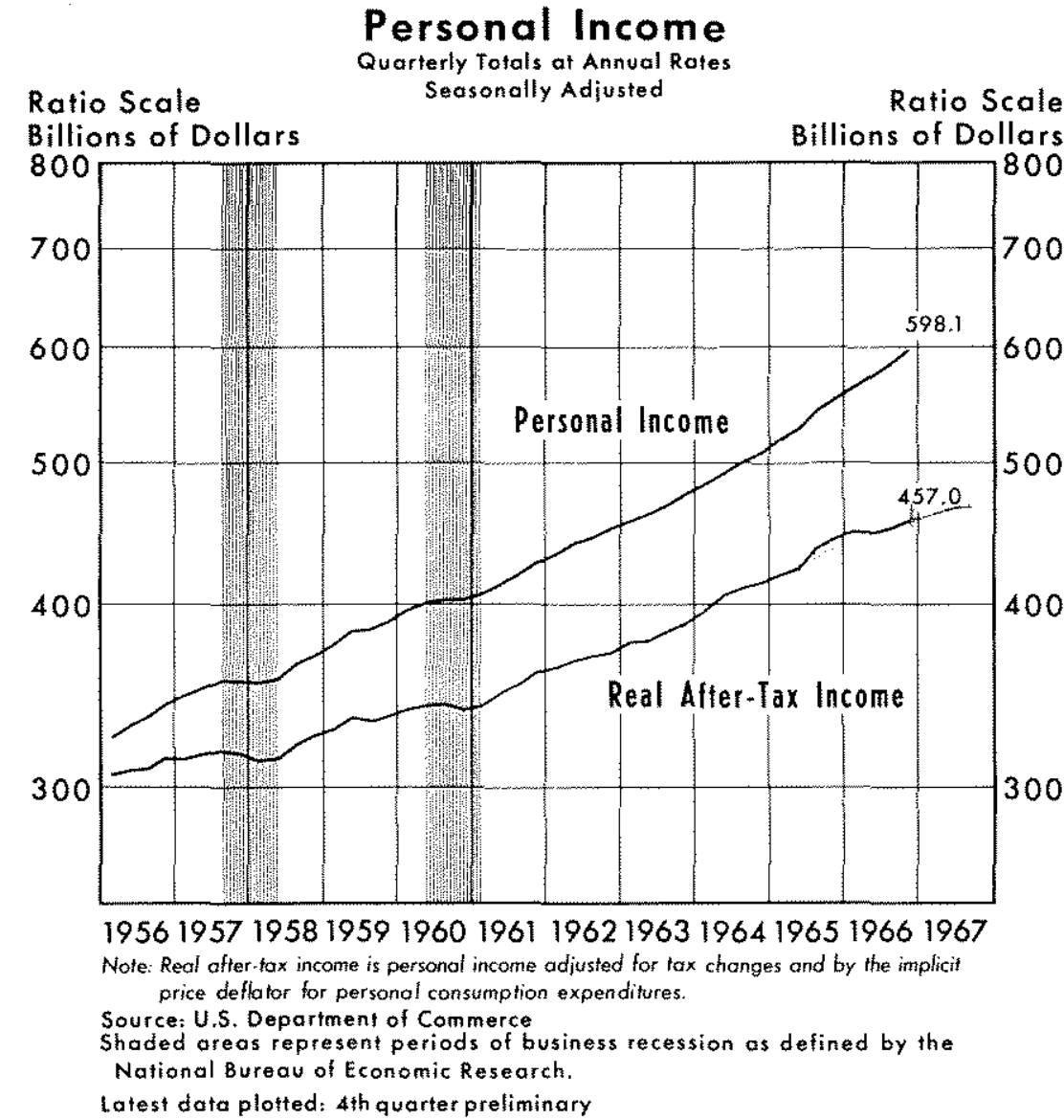

Personal Income

erly Tatals at Annual Rote

Ratio Scale

Biltions of Dollar

195619571958195919601961196219631964196519661967

pre Us. Department of Commerce

National Bureau of Economic Research.

elements of total cost, e.g., housing and commercial and industrial buildings.

The resultant rise in interest rates affected housing more than if the resource transfer had been effected by taxes. Housing probably would have been affected if incomes had been reduced by tax increases, but the extent would probably have been less. Interest rates would not have risen so rapidly, and the cost of new housing services would not have increased as much if a more restrictive course of fiscal action had been followed.

Any transfer of resources in a high-employment economy involves a cost, and some groups gain at the expense of others. However, transfer by tax increases permits the effects to be planned and regulated while maintaining the advantages of free markets. The price inflation mechanism causes inequities that are often umpredictable and creates distortions that may be in conflict with national goals of efficient resource al location and equilibrium in the balance of payments.

\section{Stabilization Policy in 1966}

The fiscal actions that were supposed to restrain demand in 1966-social security tax increases, speedup in the collection of individual and corporate in- come taxes, and rescission of scheduled excise tax cuts-came too late to thwart the inflationary pressures of the first quarter. ${ }^{\top}$ In fact, there is some question whether the 1966 first quarter experience could have been avoided (or offset) by budget actions as late as January and February of that year. Because of lags in the effect of stabilization policies, the stage may have been set for an inflationary period by a very stimulative fiscal situation in late 1965 supplemented by rapid monetary expansion in late 1965 and early 1966. The Vietnam buildup in the last half of 1965 was accompanied by excise tax reductions and a large retroactive increase in social security benefits. The money stock expanded at a 6 per cent annual rate from April 1965 to April 1966. Other key monetary variables, such as commercial bank credit and member bank reserves, also increased very rapidly during the year ending in April 1966. This combination of monetary and fiscal forces may have been sufficient to cause the first quarter 1966 excesses and the carryover with respect to prices in the second quarter (even though the advance of GNP slowed substantially in that quarter).

The restrictive budget measures that were effected -increased social security taxes, accelerated tax collections, and rescinded excise taxes-may have helped to slow the economy after the unsustainable advance in the last half of 1965 and the first quarter of 1966. These fiscal actions represented restraining factors in addition to the April turnaround in monetary growth and the implicit tax increase through inflation. Al. though Government expenditures rose substantially in the first half of 1966, these increases were more than offset by the increase in tax revenues, and the national income accounts (NIA) budget showed a surplus of $\$ 3.1$ billion compared with a $\$ 1.4$ billion deficit in the last half of 1965 .

During the second half of 1966 Federal expenditure increases outpaced the growth in receipts, resulting in a $\$ 2.7$ billion deficit in the NIA budget. Expenditures for the Vietnam war continued to rise, and some

\footnotetext{
7 Normally a change in collection procedures is not viewed a restrictive action because individuals and firms supposedly react to changes in liabtlities rather than collections. The speetup is mentioned here, however, because the 1966 CEA Report listed this action as restrictive in its effect on total demand. See pp. 53-54.
} 
domestic nondefense expenditures also rose, particularly those related to the medicare program. No direct tax increases became effective in the second half, although in October the investment tax credit was rescinded and depreciation allowances for tax purposes were tightened. These measures probably had little effect on tax revenues in 1966, although they may have affected total demand via investment decisions.

For the year 1966 the NIA budget ran a small $\$ 0.2$ billion surplus, and since the economy was at full employment the high-employment budget showed the same result. ${ }^{8}$ On this high-employment basis, this small budget surplus in 1966 indicated the most stimulative budget in more than a decade. The highemployment budget ran about in $\$ 8$ billion average surplus from 1961 to 1965 .

The stimulative budget situation in 1966 was accompanied by very restrictive monetary actions after April. The money stock showed little change from then to late fall. With loan demand fueled by rapid growth in total demand for goods and services, interest rates rose rapidly until September.

${ }^{8}$ For further discussion of the high-employment budget, see the appendix.

\section{Money Stock}

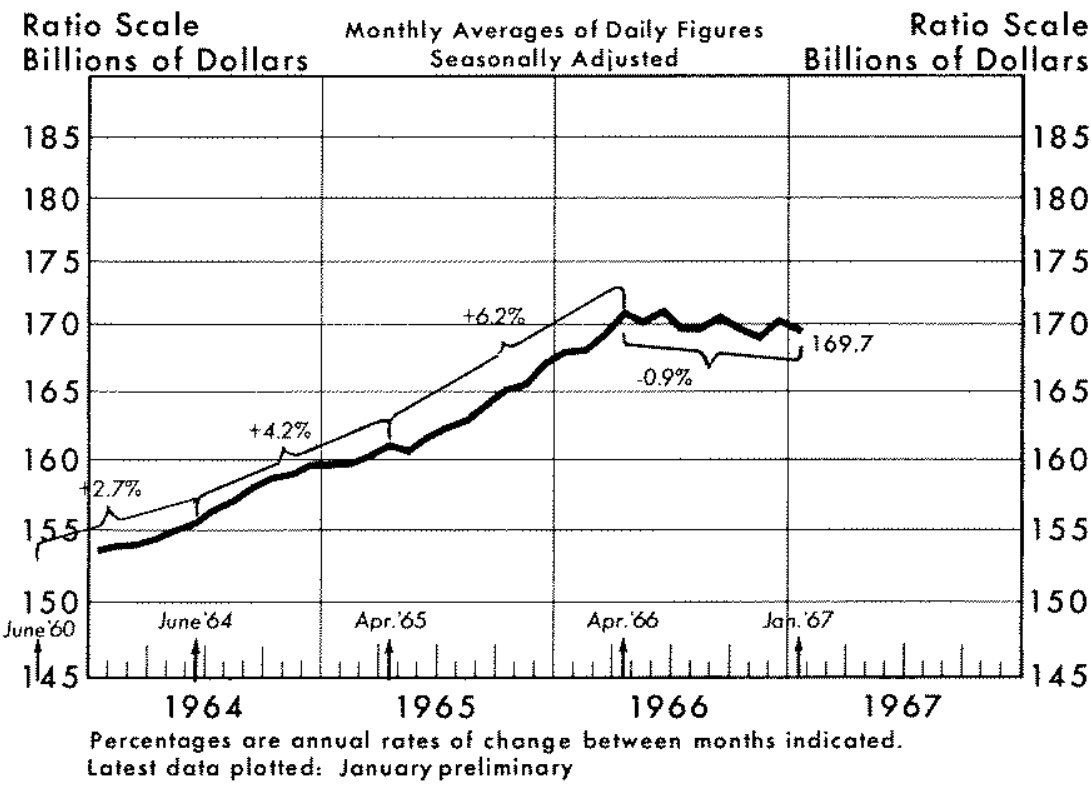

High-Employment Budget

1+1Surplus; (-1Deficit

Quarterly Totals ot Annual Rotes Secsonally Adiusted Billions of Dollars

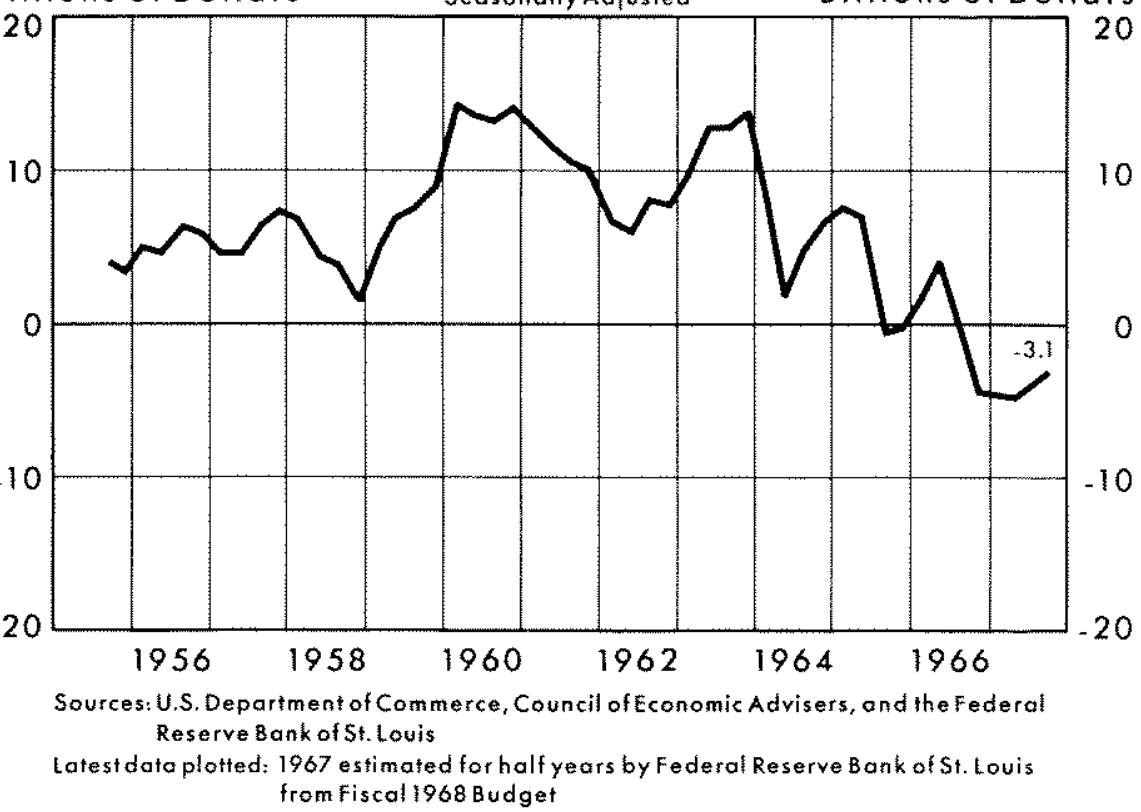

\section{Budget Program for Fiscal 1967-68}

The economic outlook for 1967 depends in large measure on the course of recent, present, and future monetary and fiscal developments. Such developments in turn are influenced by the unfolding of economic events. A forecast of economic conditions and policy must take into account this simultaneity. Presumably the Council's forecast is based on this simultaneous interaction. This section discusses in some detal the budget program for the 18-month period ending June 30, 1968 and examines budg. et policy in light of expected economic and monetary conditions.

\section{The Budget Program: A Factual Summary}

Budget plans for the next 18 months indicate a larger average deficit than in calendar 1966. This conclusion obtains for the national income accounts budget, considered to be the most complete and reliable measure of the Federal Government's activities and their economic impact.

The following summary of the fiscal program for the remainder of fiscal 1967 and fiscal 1968 is presented as general background and centers on the NIA 
budget. Fiscal year figures are given because the budget document is presented on that basis.

New Obligational Authority. Obligational authority on a cash budget basis, i.e., authority provided by Congress to obligate the Federal Government to pay out money, increases to an estimated $\$ 194.2$ billion in fiscal 1968 from $\$ 190.4$ billion in fiscal 1967 . This fiscal measure is considered by some to be a key variable in any analysis of the Federal budget.? The reason for this is that expenditures must be preceded by granting of obligational authority by Congress.

The $\$ 3.8$ billion increase in obligational authority planned for fiscal 1968 compares with an increase of $\$ 27.3$ billion in the previous fiscal year. Last year's January budget plan (i.e., for fiscal 1967) called for a $\$ 3.5$ billion increase in new obligational authority. These plans went awry, partly because of supplemental appropriations requested in January 1967 for Vietnam, but also because of larger-than-expected appropriations for housing, community development, health, education, and welfare.

Expenditures. Federal NIA expenditures in fiscal 1968 are estimated to increase 10.2 per cent over fiscal 1967, which in turn is expected to be 16.1 per cent above fiscal 1966. Fiscal 1967 expenditures are estimated at $\$ 153.6$ billion, 7.6 per cent above the figure projected a year ago for the fiscal 1967 period.

Fiscal 1968 expenditures include increases over presently estimated 1967 expenditures of $\$ 5.8$ billion or 8.5 per cent for defense and $\$ 9.8$ billion or 11.5 per cent for nondefense spending including expanded social security benefits. The increases in fiscal 1967 over fiscal 1966 are 20.9 per cent for defense and

${ }^{9}$ See the writings of Murray L. Weidenbaum, e.g. "The Timing of the Economic Impact of Government Spending," National Tax Journal (Mareh 1959), pp. 79.85.
CHANGES IN OBLIGATIONAL AUTHORITY

Cash Budgef

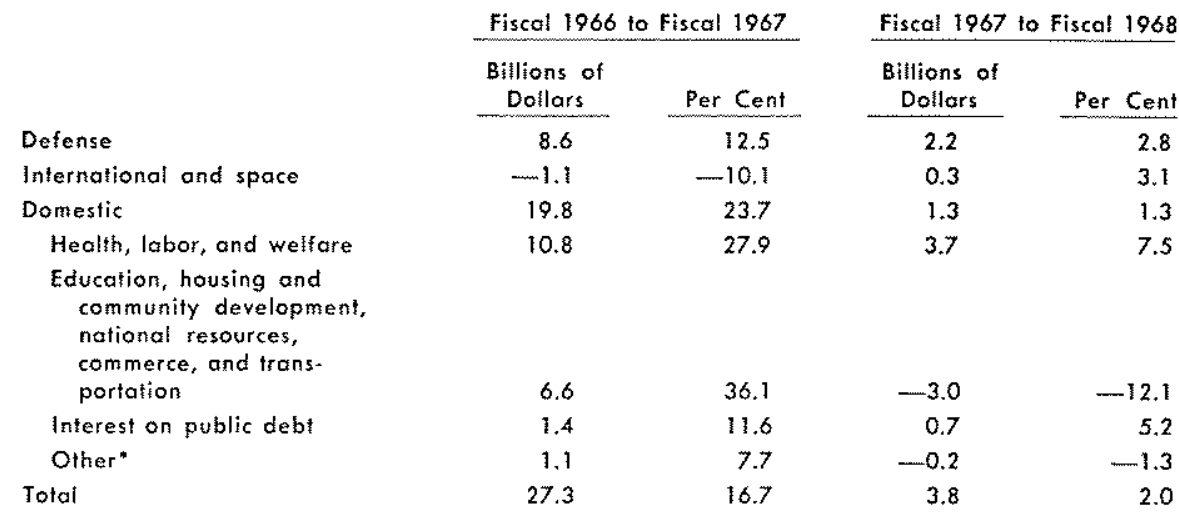

*Agriculturs, veterans" benefts and serwices, general govermingt, civiliza and military pay increases.

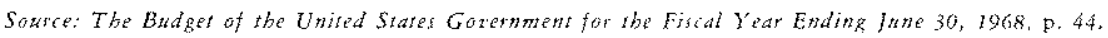

\begin{tabular}{|c|c|c|c|c|}
\hline & $\begin{array}{l}\text { IN FEL } \\
\text { Income }\end{array}$ & $\begin{array}{l}\text { SPEND } \\
\text { unts Bud }\end{array}$ & & \\
\hline & Fiscal 1966 & scal 1967 & Fiscal 1967 & iscal 1968 \\
\hline & $\begin{array}{l}\text { Bilfions of } \\
\text { Doflars } \\
\end{array}$ & Per Cent & $\begin{array}{c}\text { Billions of } \\
\text { Dollars }\end{array}$ & Per Cent \\
\hline Defense & 11.8 & 20.9 & 5.8 & 8.5 \\
\hline International and spoce & - & - & -0.2 & -2.3 \\
\hline Domestic & 9.5 & 14.2 & 10.0 & 13.1 \\
\hline Health, labor, and welfore, & 6.2 & 18.8 & 7.2 & 18.4 \\
\hline $\begin{array}{l}\text { Education, housing and } \\
\text { community development, } \\
\text { notural resources, } \\
\text { commerce, and trans- } \\
\text { portation }\end{array}$ & 2.0 & 16.7 & 0.9 & 6.4 \\
\hline Interest on public debt & 0.9 & 9.2 & 0.2 & 1.9 \\
\hline Other* & 0.4 & 3.3 & 1.8 & 14.3 \\
\hline Total & 21.3 & 16.1 & 15.6 & 10.2 \\
\hline
\end{tabular}

*Agriculture, veterans' benefts and services, general government, civilian and military pay increases, Sorsce: The Butget of the United States Goternment for the Firal Year Ending Jone 30, 1968, p. 43.

CHANGES IN FEDERAL RECEIPTS

National Income Accounts Budget

Changes due to changes in lax law

\begin{tabular}{|c|c|c|c|}
\hline \multicolumn{2}{|c|}{ Fiscal 1966 to fiscal 1967} & \multicolumn{2}{|c|}{ Fiscal 1987 to Fiscal 1968} \\
\hline $\begin{array}{c}\text { Billions of } \\
\text { Dollars }\end{array}$ & $\begin{array}{l}\text { Per Cent of } \\
1956 \text { Receipts }\end{array}$ & $\begin{array}{c}\text { Billions of } \\
\text { Dollors }\end{array}$ & $\begin{array}{l}\text { Per Cent of } \\
1967 \text { Receipts }\end{array}$ \\
\hline 7.0 & 5.3 & 5.8 & 3.9 \\
\hline 1.2 & 0.9 & 3.4 & 2.2 \\
\hline- & - & 1.9 & 1.3 \\
\hline- & - & -.5 & -0.3 \\
\hline 5.8 & 4.4 & 1.0 & 0.7 \\
\hline 10.2 & 7.7 & 11.5 & 7.7 \\
\hline 17.2 & 13.0 & 17.3 & 11.6 \\
\hline
\end{tabular}

Sourc: Estimated by Federal Reserve Bank of St. Louis from The Budget of the United States Governmett for the Fisal Year Ending June 30, 1968.

12.5 per cent for nondefense programs.

Receipts. Federal NIA receipts are expected to rise less rapidly than expenditures from fiscal 1967 to fiscal 1968, thereby increasing the deficit. Increases in receipts were large in fiscal 1966 and even larger in 


\section{National Income Accounts Budget}

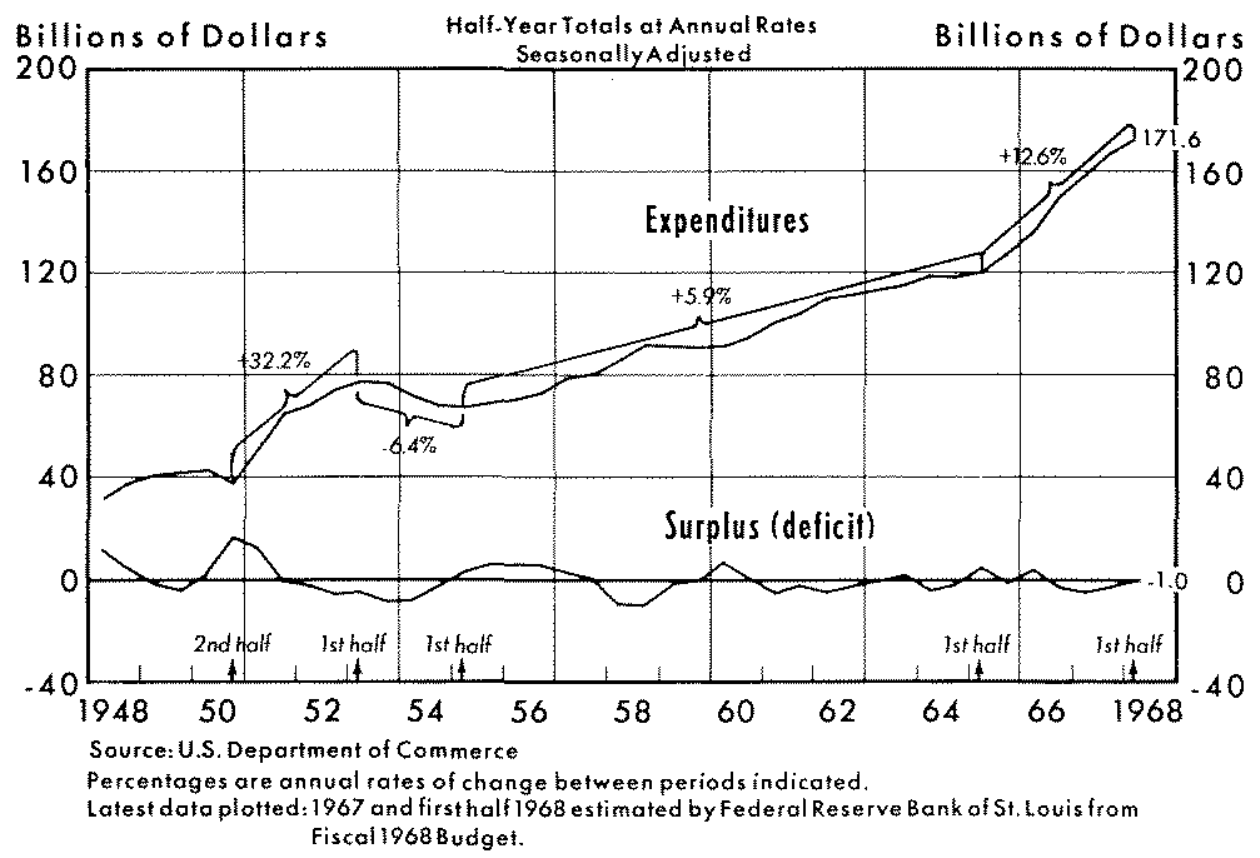

stability. The budget is presumably designed to provide just the right amount of fiscal stimulus or restraint at the appropriate time. The success of the proposed budget program depends on the vagaries of private demand and the response of private demand to monetary and fiscal actions. Fundamental to success is whether budget policy is sufficiently flexible to move in accordance with changing economic and monetary conditions.

The budget program for the first half of calendar 1967 is essentially determined. Forces governing the course of expenditures and receipts are already in motion. The CEA indicates fiscal 1967. Such increases have resulted primarily because this was a period of rapidly expanding money incomes and inflation. Receipts were also accelerated, however, by faster collections and increases in social security tax rates during this period.

NIA receipts are anticipated to increase by $\$ 17.3$ billion or 11.6 per cent in fiscal 1968 over the previous fiscal year. Growth in receipts will result mainly from continued economic expansion but will also reflect the proposed 6 per cent surcharge on personal and corporate income effective July 1,1967 and a scheduled increase in social security tax rates on January 1 , 1968.

\section{Budget Policy in its Economic Setting}

Budget plans for calendar 1967 are predicated on a forecast of sluggish growth in private demand in the first half of the year with a resumption of more rapid growth in the second half. The purpose of this section is to examine Federal budget plans within the economic setting expected in calendar 1967.

An evaluation of the Federal budget plan at this particular time is replete with problems. The Council of Economic Advisers probably has access to more information than anyone else at the time of the budget's preparation. Consequently, this examination of the budget centers more on assumptions than on the internal consistency of the proposed total economic plan.

The economic plan, as presented in the Fiscal 1968 Budget and the CEA Report, is to keep the economy on a full-employment growth path with relative price that the sizable stimulus of a $\$ 5$ billion NIA deficit will be appropriate in its timing and magnitude of impact on an economy characterized by weakening private demand.

Included in the budget program for the second half of 1967 is a proposed surtax which is supposed to provide restraint on strengthening private demand at that time. Such plans provide flexibility in that the surtax proposal could be dropped if economic conditions do not warrant fiscal restraint. Furthermore, if inflationary pressures intensify, the surtax rate could be increased above that which is proposed.

The 1966 experience suggests that budget policy was not sufficiently flexible to counter movements in private demand. During the first quarter of 1966 , when it was quite obvious that further monetary or fiscal restraint was required, budget policy fell short as an instrument of stabilization. Fiscal restraint was not forthcoming because of the slow and cumbersome nature of the budget machinery. It was not possible to implement a tax increase because of the slowness of the Congressional process. Furthermore, most Government spending programs are of the type that cannot be slowed or speeded in accordance with the desire of the policymaker. Because of the relative inflexibility of fiscal policy, it was necessary for monetary policy to carry the burden of stabilization in 1966.

Taking these considerations into account, it appears that monetary policy may again be assigned a critical role in the total of stabilization policy in 1967. Monetary policy is flexible in its implementation, though 
there is a question about flexibility in its impact. Incomplete knowledge of the magnitude and timing of monetary actions on economic activity indicates that it should be used carefully as a tool of stabilization policy. ${ }^{10}$

Uncertainty about the length and variability of time lags in the implementation and effect of monetary and fiscal policy suggests that stimulus or restraint be applied in moderate doses when the economy is at high employment. Large adjustments in policy variables

10 Some evidence has recently been presented to support the view that monetary actions may affect total demand quite guickly via portfolio behavior of holders of liquid assets. See Donald P. Tucker, "Dynamic Income Adjustment to Money Supply Changes," American Economic Review (June 1966), pp. $433-449$. may cause instability, which is precisely what policymakers are trying to avoid.

The economic situation in early 1967 is believed to dictate a need for more stimulative economic policy. An indication that the fourth quarter 1966 increase in GNP contained some involuntary accumulation of inventory portends further slowing of production and attempts to reduce inventory. Since fiscal and monetary policies tend to affect total demand with lags, excessive stimulation in the next few months might be too late to avert a slowdown in the first half of 1967 but might create serious inflationary problems in the second half. On the other hand, insufficient stimulation might cause the slowdown to continue well into the second half.

Keith M. Carlson

\section{APPENDIX}

\section{Budget Concepts and Definitions}

The fiscal activities of the Federal Government can be summarized in several ways. Some alternative budget concepts and the relationships between them are discussed in this appendix. A table reconciling these budget concepts is given, with data for fiscal 1966-68 used for illustration.

\section{Administratite Budget}

The administrative budget is the basic planning document of the Federal Govermment, covering receipts and expenditures of funds that it owns. Its main purpose is to serve as a guide to executive and legislative program planning, review, and enactment. The administrative budget is in fact the only Federal "budget" in the sense of a financial plan. All other "budgets" discussed here are summary statements of receipts and expenditures classified in various ways for purposes other than administrative planning.

Those agencies for which Congress makes regular appropriations are included in the administrative budget. Public enterprises ${ }^{1}$ are included while trust funds ${ }^{x}$ and Government-sponsored agencies ${ }^{3}$ are not.

Expenditures and receipts are generally recorded on a cash basis, i.e, on the date of actual receipt or payment. Interest expense is on an accrual basis.

\section{Cash Bufluet}

The consolidated cash budget is a summary statement

${ }^{ \pm}$Commodity Credit Corporation, Federal National Mortgage Association, Export-Import Bank, etc.

${ }^{2}$ Federal Old-Age and Survivors Insurance, Unemployment Trust Fund, Highway Trust Fund, etc.

${ }^{3}$ Federal Home Loan Banks, Federal Land Banks, Federal Intermediate Credit Banks, and Banks for Cooperatives. of cash flow between the Federal Government and other sectors of the economy. Included are activities of the regvar Government agencies found in the administrative budget plus the activities of trust funds and Governmentsponsored agencies. Because activities of some agencies (e.g, the post office) are recorded on a net basis, the full magnitude of cash flows between the Federn Government and other sectors of the economy is not measured by the cash budget.

The cash surplus or deficit serves as a measure of the direct impact of Federal Government spending and taxation on the financial assets of the private sector of the economy (including state and local governments). Surpluses or deficits in this budget indicate changes in the public debt and/or changes in the Treasury's cash balance.

\section{National Income Accounts Budget}

The national income accounts budget summarizes the receipts and expenditures of the Federal Government sector as an integrated part of the recorded activities (i.e., the national income accounts) of all sectors of the economy. Primary differences between the cash budget and the national income accounts budget are (1) on the expenditure side, spending is recorded when delivery is made to the Government, and purchases and sales of existing real and financial assets are excluded, and (2) on the receipts side, taxes are in large measure recorded when the tax liability is incurred.

\section{IIigh-Employment Budget}

The high-employment budget is an estimate of expenditures and revenues in the Federal sector of the national 
income accounts for a level of high employment. ${ }^{4}$ it is an attempt to correct the distortion introduced by the impact of the economy itself (through the effect of changing levels of economic activity on Government expenditures and tax receipts) on the realized surplus or deficit. The smalles the surplus or greater the deficit in this budget, the more stimulative is the impact of Federal fiscal activities and the less is the dependence on private demand to maintain high employment.

\section{New Obligational \\ Authority}

Another measure of particular importance in evaluating the impact of the Federal Government on the economy is "new obligational author. ity." This is legislation by Congress permitting a Government agency or department to commit or obligate the Government to certain expenditures. Congress does not vote on expenditures; it determines new obligational authority. Before funds can be spent, an agency must submit and have approved by the Bureau of the Budget an apportionment request. This determines the rate at which obligational authority can be used. An agency usually incurs obligations, i.e., commits itself to pay out money, after apportionment by the Bureau of the Budget.

\footnotetext{
4The President's Council of Economic Advisers defines a high-employment level of economic activity as that level associated with a 4 per cent unemployment rate. The highemployment budget could be computed for other budget concepts, but, for an analysis of the economic impact of the budget, the national income accounts basis seems most appropriate. For a description of techniques and procedures for calculating high-employment budget estimates, see Nancy H. Teeters, "Estimates of the Full-Employment Surplus, 1955-1964", The Review of Economics and Statistics, XLVII (August 1965), pp. $309 \cdots 321$.
}

Incurring obligations does not necessarily mean immediate cash expenditures. When the Government buys goods and services produced by the private sector, the lag of expenditures behind obligations may be substantial. In the case of items not usually kept in inventory, like military hardware, it usually takes time for private producers to draw plans, negotiate subcontracts, produce, and deliver the product.

\section{RECONCILIATION OF VARIOUS MEASURES OF FEDERAL RECEIPTS AND EXPENDITURES}

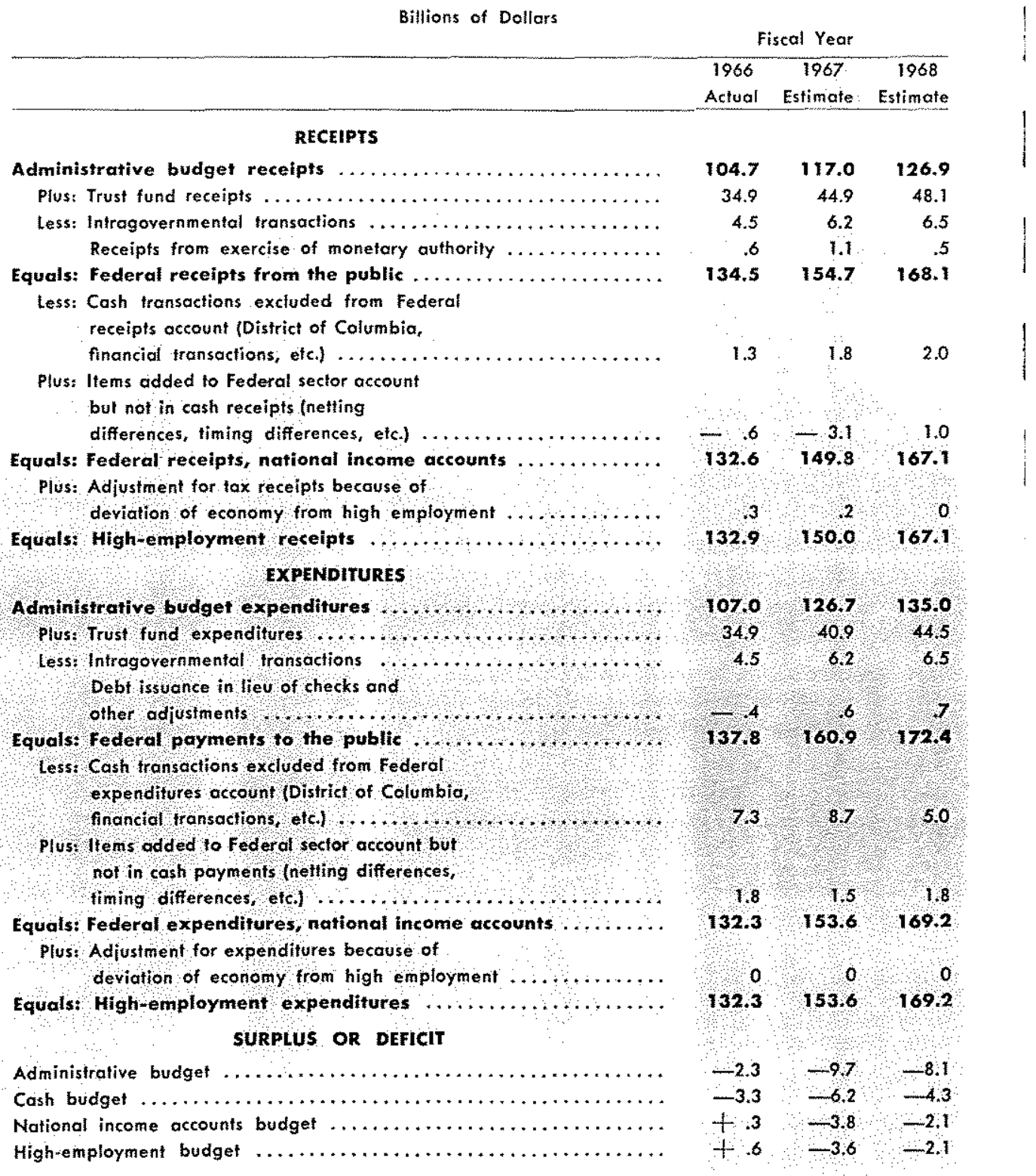

Soures: The Budget of the United 5tates Gotermment for the Fiscal Year Ending Jtthe 30 , 1968 and Federal Reserve Bank of St. Lotis.

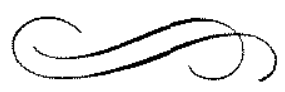

Page 12 